\title{
When environmental changes do not cause geographic separation of fauna: differential responses of Baikalian invertebrates
}

\author{
Varvara Fazalova ${ }^{1,2^{*}}$, Bruno Nevado ${ }^{3,4}$, Tatiana Peretolchina', Jeanna Petunina', Dmitry Sherbakov ${ }^{1,5}$
}

\begin{abstract}
Background: While the impact of climate fluctuations on the demographic histories of species caused by changes in habitat availability is well studied, populations of species from systems without geographic isolation have received comparatively little attention. Using CO1 mitochondrial sequences, we analysed phylogeographic patterns and demographic histories of populations of five species (four gastropod and one amphipod species) co-occurring in the southwestern shore of Lake Baikal, an area where environmental oscillations have not resulted in geographical isolation of habitats.

Results: Species with stronger habitat preferences (gastropods B. turriformis, B. carinata and B. carinatocostata) exhibit rather stable population sizes through their evolutionary history, and their phylogeographic pattern indicates moderate habitat fragmentation. Conversely, species without strong habitat preference (gastropod $M$. herderiana and amphipod G. fasciatus) exhibit haplotype networks with a very abundant and widespread central haplotype and a big number of singleton haplotypes, while their reconstructed demographic histories show a population expansion starting about 25-50 thousand years ago, a period marked by climate warming and increase in diatom abundance as inferred from bottom-lake sedimentary cores.
\end{abstract}

Conclusions: In agreement with previous studies, we found that species reacted differently to the same environmental changes. Our results highlight the important role of dispersal ability and degree of ecological specialization in defining a species' response to environmental changes.

\section{Background}

Many studies have demonstrated the strong influence of climate fluctuations on the patterns of genetic diversity of species. Continental glaciations resulted in geographic isolation of terrestrial species by affecting habitat availability $[1,2]$. After the climate warming, some species experienced demographic expansions and occupied newly created habitats [3-5]. Additionally, climate cooling was linked with low level of oceans and lakes [6]. When the water level decreased, marine species could experience range contractions and this again resulted in change of their phylogeographic patterns $[7,8]$. On the other hand, low ocean level affects the connectivity of islands

\footnotetext{
* Correspondence: fazalova@iiasa.ac.at

'Laboratory of Molecular Systematics, Limnological Institute of the Siberian Branch of the Russian Academy of Sciences, Ulan-Batorskaya 3, 664033

Irkutsk, Russia

Full list of author information is available at the end of the article
}

and the distribution of species inhabiting them [9]. However, analysis of the demographic histories of species from northeastern Pacific showed that half of them were not affected by climatic changes in the Pleistocene [10]. This suggests that, even if the majority of studies consider geographic isolation as a driving force of changes in demographic histories, impact of climate cooling on ecological systems could be more complex. For example, switches in oceanic thermohaline circulation could change distribution and abundance of food and result in a bottleneck [11]. Furthermore, in systems where environmental changes resulted in isolation of populations, the present genetic structure of populations will reflect to a great degree the changes in genetic diversity due to random evolution in these isolated populations. As such, analysis of current patterns of diversity will be affected by this, as well as by the demographic histories of the populations, or the presence/absence of selective pressures.

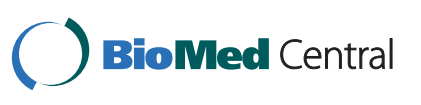

(c) 2010 Fazalova et al; licensee BioMed Central Ltd. This is an Open Access article distributed under the terms of the Creative Commons Attribution License (http://creativecommons.org/licenses/by/2.0), which permits unrestricted use, distribution, and reproduction in any medium, provided the original work is properly cited. 
Conversely, in systems where geographical isolation is absent one can distinguish the effect of genetic drift in small isolated populations from the demographic changes brought about by the environmental changes themselves. It therefore seems appropriate to study ecosystems that are known to be affected by environmental changes, but where these changes did not lead to geographic separation of populations.

Ancient lakes are famous for their high level of biodiversity. Whereas many studies on speciation were devoted to the fauna of ancient lakes, reconstruction of their demographic histories received little attention (but see e.g. [12]). Lake Baikal is the largest freshwater continental ecosystem [13], and given its high-latitude location it is particularly sensitive to climatic variations [14]. Despite the great depth of the lake (c. $1650 \mathrm{~m})$, its water is well oxygenated throughout, creating unique habitats. The sediments of the lake are one of the most valuable continental climatic archives having uninterrupted record back to Late/Middle Miocene [15,16]. The paleoclimatic history of Lake Baikal was reconstructed based on records of diatom and associated biogenic silica in sediments, their variation corresponding to the Marine Isotope Stages (MIS) of climate change [17-23]. Additionally, sedimentary photosynthetic pigments provide more data about past productivity of the lake by representing the whole assemblage of phytoplankton $[24,25]$. Numerous strong environmental changes were identified during the Upper and Middle Pleistocene [21,26-29] and the Holocene [18,30,31]. Also there is evidence for water level fluctuations during periods of climatic cooling [32,33]. While Lake Baikal is known to have been affected by environmental changes, the lake's geological structure suggests that these changes have not affected the connectivity of habitats. Previous studies on the genetic variation of invertebrates from the lake revealed variation of population dynamics presumably caused by geological events (tectonic shifts), changes in global climate and related changes in sedimentation rate [34].

Recent studies comparing the demographic histories of multiple co-occurring species $[10,35,36]$ found that populations of these species responded in different ways to the same environmental changes. However, exact causes for such differences were often difficult to distinguish given the numerous biological differences between the investigated species. We thus compare, in this study, species with very similar biological traits and life-history characteristics, allowing us to identify the factors responsible for the species' differential response to environmental changes. This approach has already proved valuable in understanding key aspects of the response of species to fluctuation of environmental conditions (e.g. see $[37,38]$ ). We focus on four gastropod species of the family Baicaliidae: Baicalia carinata (W. Dybowski, 1875) is an abundant sand dwelling species with a circum-lacustrine distribution; Baicalia carinatocostata (W. Dybowski, 1875) is often found in sandy habitats together with $B$. carinata but usually in smaller numbers; Maackia herderiana dominates the rocky surfaces but is also found in lower abundance in sandy and silty substrates in the southwestern shore of the lake [39]; and Baicalia turriformis (W. Dybowski, 1875) inhabits rocks along the same shoreline as $M$. herderiana (Lindholm, 1909). The four species also use different egg-laying substrate: $B$. carinata lays its eggs on the surface of the shell of other conspecifics; $B$. carinatocostata lays its eggs in sand; $M$. herderiana uses cavities of stones; and $B$. turriformis attaches its eggs to smooth surfaces of rocks [40,41]. Juveniles of these gastropods emerge directly from egg capsules and therefore the dispersal ability of these species is low when compared to other gastropods with free-swimming, planktonic larvae. For comparative purposes, we included in this study data from the amphipod Gmelinoides fasciatus (Stebbing, 1899). It is found in high abundances in sandy and rocky bottoms in almost all littoral zones of the lake at water depths between 0 and 5 meters. This species is a successful invader that rapidly increases its population size when introduced in new ecosystems $[42,43]$ and this suggests that it might represent a good proxy for habitat and food availability. All four gastropod species and G. fasciatus are suspension feeders and have similar dietary preferences. Observations on the stomach content of the gastropods showed that they mainly consume planktonic diatoms Aulacoseira baicalensis, A. islandica, Cyctotella baicalensis and C. minuta [44]. These diatom species significantly contribute to the paleo-record of the lake and their abundance reflects the bioproductivity of the ecosystem. It therefore seems appropriate to use the paleoclimatic history (based on record of sediments) to study the impact of past environmental changes on the species herein investigated.

In this study we investigated how demographic histories of several co-occuring species with different ecological preferences were affected by environmental changes in an ecosystem where these changes did not cause geographical separation of fauna. To this end we collected mitochondrial DNA data (CO1) from populations of five species from the southwestern shore of Lake Baikal. We examined phylogeographic patterns and performed comparative analysis of the demographic histories of these populations in view of the known past environmental changes.

\section{Results}

Our taxon sampling included 222 individuals from the five targeted species collected from 13 localities. The list 
Table 1 Sampling localities and number of samples of each species used in this study

\begin{tabular}{|c|c|c|c|c|c|c|}
\hline Locality & Locality No. & B. carinata & B. carinatocostata & B. turriformis & G. fasciatus & M. herderiana \\
\hline Angara River & 1 & - & - & - & 7 & - \\
\hline Murinskaya Banka & 2 & 14 & 2 & - & - & 5 \\
\hline Utulik & 3 & 3 & - & - & - & - \\
\hline Kultuk & 4 & 5 & 6 & 3 & - & 4 \\
\hline Polovinnaya Bay & 5 & - & 4 & 5 & 17 & 16 \\
\hline Listvyanka & 6 & - & - & 10 & 7 & 19 \\
\hline Bolshie Koty & 7 & 2 & - & 3 & - & 9 \\
\hline Varnachka & 8 & - & - & 4 & - & - \\
\hline Peschanaya Bay & 9 & 3 & 5 & - & 4 & - \\
\hline Bugul'deika & 10 & 2 & - & - & 3 & 25 \\
\hline Tutaiskaya Bay & 11 & 7 & - & - & - & - \\
\hline Olkhon Gates & 12 & 21 & 2 & - & 2 & - \\
\hline Zunduk Cape & 13 & - & - & - & 3 & - \\
\hline Total No. & - & 57 & 19 & 25 & 43 & 78 \\
\hline
\end{tabular}

of sampling localities is shown in Table 1 (for details please see Additional file 1). Haplotype networks for the investigated species show different patterns of genetic variation (Figure 1). Most of $M$. herderiana individuals carry the same haplotype and there is a number of singleton haplotypes, this suggests population growth. The same pattern is exhibited by G. fasciatus, with a dominating haplotype and a small number of less abundant haplotypes. Conversely, haplotypes found in B. carinata, $B$. carinatocostata and $B$. turriformis are very diverse and distributed throughout the network. In B. carinata and $B$. carinatocostata very different haplotypes were found in several localities, some of which were resolved in separate networks.

Tables of pairwise $F_{S T}$ values and their significance levels for each studied species are shown in Additional file 2 . The studied species exhibited variable level of geographic structuring, from total absence of significant $\mathrm{F}_{\mathrm{ST}}$ values between pairs of localities (G. fasciatus) to significant $\mathrm{F}_{\mathrm{ST}}$ values between almost all of these comparisons (B. turriformis).

Results of comparative analysis of mismatch distributions $[45,46]$ for each species are depicted in Figure 2. Mismatch distributions of $M$. herderiana and G. fasciatus exhibit similar shape with most pairwise comparisons having small genetic distances, showing a relatively good fit to the expected mismatch distributions under the model of population growth. Conversely, the mismatch distributions of $B$. carinata, $B$. carinatocostata and $B$. turriformis are rather multimodal and ragged, and contain a higher proportion of comparisons resulting in larger genetic distances.

Table 2 summarizes the intraspecific statistics estimated for each species: number of sequences, number of segregating sites, number of haplotypes, nucleotide diversity, haplotype diversity and average number of nucleotide differences. Felsenstein [47] suggests that eight haplotypes randomly sampled from a single panmictic population allow accurate estimates of population genetics' parameters. Therefore, our sampling effort seems adequate (only for $B$. turriformis were less than 8 haplotypes recovered in this study). Despite small sample sizes, B. turriformis and B. carinatocostata exhibited high nucleotide diversity, while the lowest nucleotide diversity was found in $M$. herderiana (0.0019).

Maackia herderiana is the only species for which classic tests rejected the hypothesis of neutrality, with Ramos-Onsins' R2 test against population expansion being significant (see Table 3). G. fasciatus exhibited low, though non-significant, p-values for Ramos-Onsins $\mathrm{R} 2$ and Tajima's D tests. $\mathrm{H}$ test showed no purifying selection for any of the investigated species.

Figure 3 summarizes results of Bayesian skyline reconstructions of demographic histories for sand dwelling (a) and for rock dwelling (b) gastropod species, and also for G. fasciatus (c). Sand dwelling B. carinata and B. carinatocostata show rather stable population sizes as does the rock-dwelling B. turriformis. Maackia herderiana shows a dramatic population expansion and G. fasciatus shows signs of population growth. Results of Bayesian Skyline Plots (BSPs) were not influenced by the change of the substitution model for G. fasciatus (see Additional file 3 ). Figure $3(\mathrm{~d})$ shows the relative duration of the recovered demographic histories. The most recent common ancestors of the populations of $M$. herderiana and G. fasciatus are relatively recent when compared to $B$. carinata, B. carinatocostata and B. turriformis. Figure 4 shows the calibrated demographic histories of 


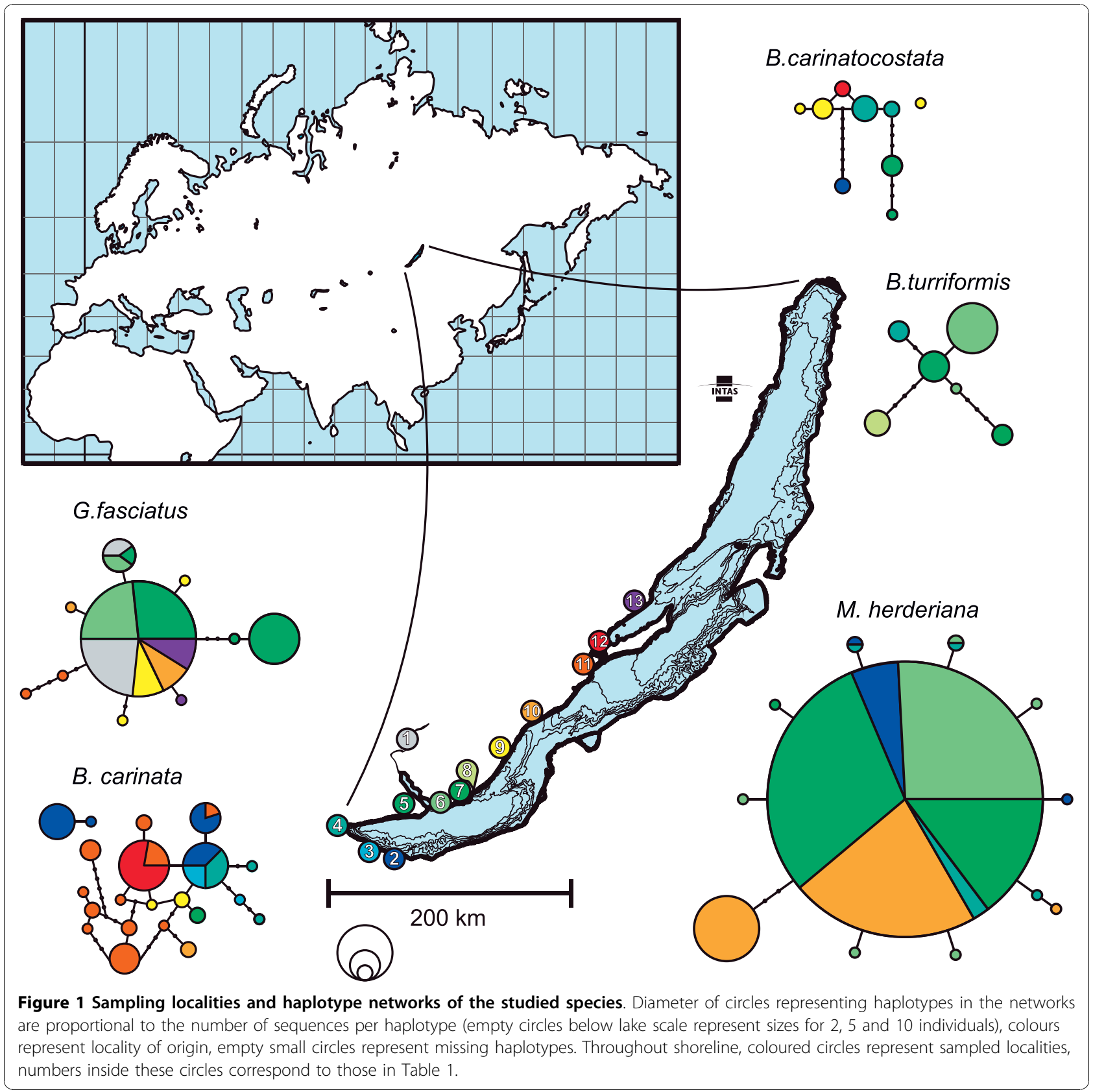

G. fasciatus and M. herderiana, and the known lakelevel fluctuations and diatom abundance through time inferred from sedimentary cores. Start of the population expansions in both species occurred during a period of relatively high water level, and coincided with a period of high diatom abundance c. 25-50 Kyr BP (thousand years before the present).

\section{Discussion}

In this study we compared phylogeographic patterns and demographic histories of species with similar feeding preferences inhabiting the same geographical area of Lake Baikal. Overall, we found three different phylogeographic patterns in the five species investigated. Both $M$. herderiana and G. fasciatus exhibit haplotype networks in which a central haplotype is very abundant and widespread, and to which several less common haplotypes are closely related. Baicalia carinatocostata and B. turriformis display very different pattern, with the same haplotype never found in more than one locality and lacking a central and most abundant haplotype. Baicalia carinata shows an intermediate picture, with some 

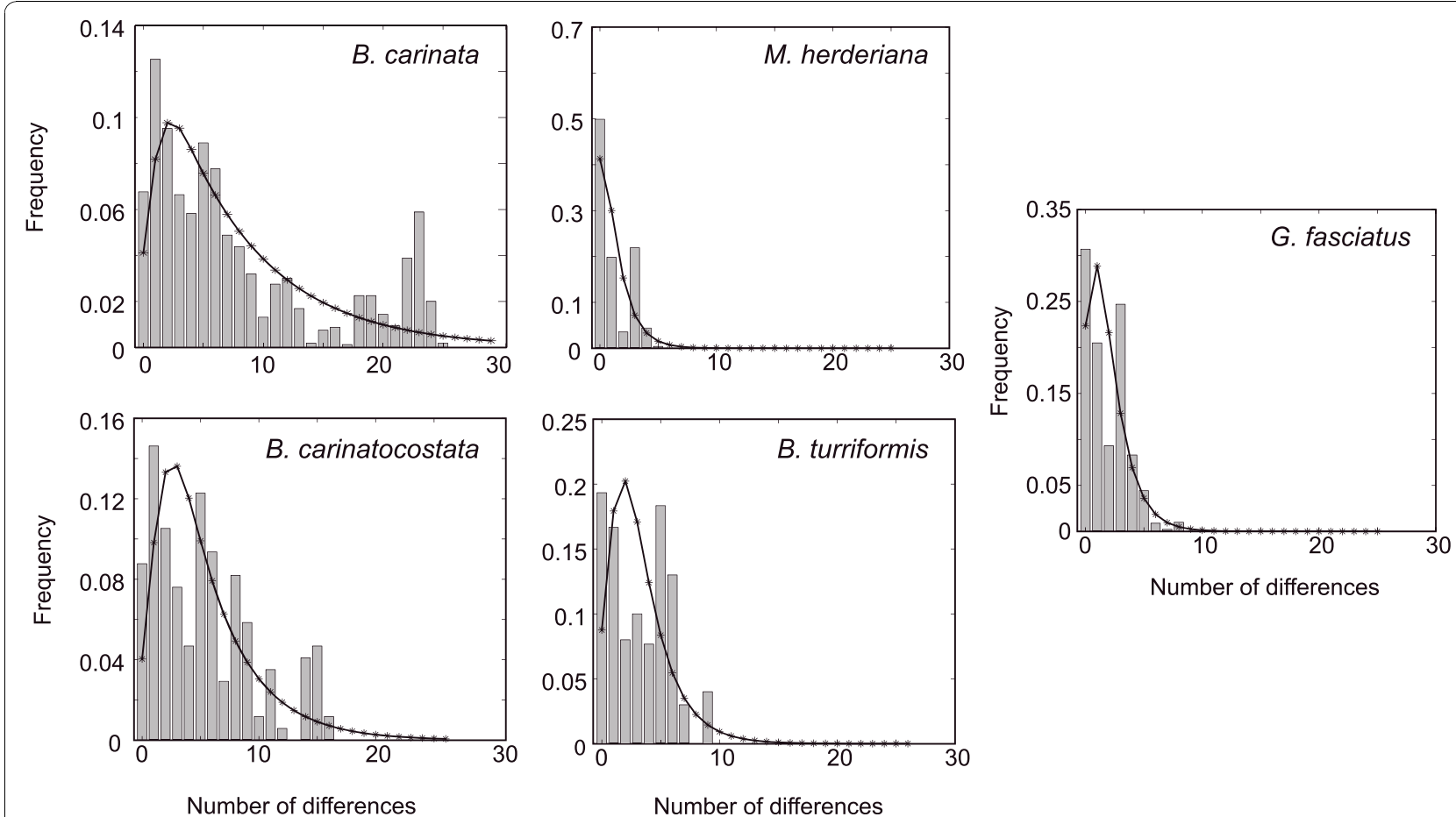

Figure 2 Mismatch distributions for the studied species. Bars represent observed values, lines represent expected values under model of sudden population growth (estimated in DNAsp).

relatively abundant haplotypes being found in different localities and rare haplotypes restricted to single sampling localities.

While phylogeographic patterns often reflect habitat availability and connectivity $[8,48]$ our results suggest that intrinsic biological factors might play an important role in shaping the genetic structure of the species analyzed. The southwestern shore of Lake Baikal, which was sampled for this study, has relatively few sandy areas, with a mostly steep, rocky shoreline (Additional file 4). One would thus expect that species inhabiting mostly sandy bottoms would show high geographic substructuring, while species that prefer rocky habitats would exhibit a pattern indicative of relatively uninterrupted gene flow. Our results, however, are only

Table 2 Summary statistics of genetic variation for each species

\begin{tabular}{ccccccc}
\hline Species & $\mathbf{N}$ & $\mathbf{S}$ & $\mathbf{h}$ & $\mathbf{P i}$ & $\mathbf{H d}$ & $\mathbf{k}$ \\
\hline B. carinata & 57 & 29 & 21 & 0.0136 & 0.932 & 8.014 \\
\hline B. carinatocostata & 19 & 24 & 10 & 0.0091 & 0.912 & 5.368 \\
\hline B. turriformis & 25 & 12 & 6 & 0.0054 & 0.807 & 3.200 \\
\hline G. fasciatus & 43 & 14 & 10 & 0.0033 & 0.693 & 1.834 \\
\hline M. herderiana & 78 & 13 & 12 & 0.0019 & 0.501 & 1.123
\end{tabular}

$\mathrm{N}$ - number of sequences; $\mathrm{S}$ - number of segregating sites; $\mathrm{h}$ - number of haplotypes; $\mathrm{Pi}$ - nucleotide diversity; $\mathrm{Hd}$ - haplotype diversity; $\mathrm{k}$ - average number of nucleotide differences. partially supportive of this hypothesis. Concerning $M$. herderiana, it should be noted that although inhabiting mostly rocky areas, this species has been found in both sandy and silted areas [39]. In this regard, M. herderiana resembles the generalist amphipod G. fasciatus, which lives in both sandy and rocky substrates $[49,50]$ and is further known to easily invade new habitats and occupy places in ecosystems $[42,43,51]$. These two species show remarkably similar phylogeographic patterns, with our data suggesting high degree of gene flow throughout the studied geographic range. The inferred patterns for the remaining three species analysed, however, highlight the importance of specific biological characteristics other than preferred habitat type. In fact, $B$. carinata and $B$. carinatocostata both live in sandy bottoms, but show

Table 3 Statistical tests of neutrality calculated for each species

\begin{tabular}{ccccc}
\hline Species & Fs & R2 & D & H \\
\hline B. carinata & $-1.76(0.28)$ & $0.137(0.86)$ & $0.89(0.84)$ & $0.79(0.91)$ \\
\hline B. carinatocostata & $-0.027(0.51)$ & $0.122(0.41)$ & $-0.85(0.23)$ & $0.827(0.89)$ \\
\hline B. turriformis & $0.05(0.52)$ & $0.127(0.62)$ & $-0.07(0.55)$ & $0.116(0.31)$ \\
\hline G. fasciatus & $-2.64(0.164)$ & $0.067(0.08)$ & $-1.35(0.09)$ & $0.684(0.81)$ \\
\hline M. herderiana & $-0.19(0.56)$ & $\mathbf{0 . 0 9 9}(\mathbf{0 . 0 4 3 )}$ & $-0.05(0.55)$ & $0.05(0.27)$
\end{tabular}

Fs - Fu's Fs index; R2 - Ramos-Onsins R2 test; D - Tajima's D; H - Fay and Wu's $\mathrm{H}$ statistics. In parentheses, $\mathrm{p}$-values are given for each statistics. Results of significant tests $(p<0.05)$ are shown in bold. 

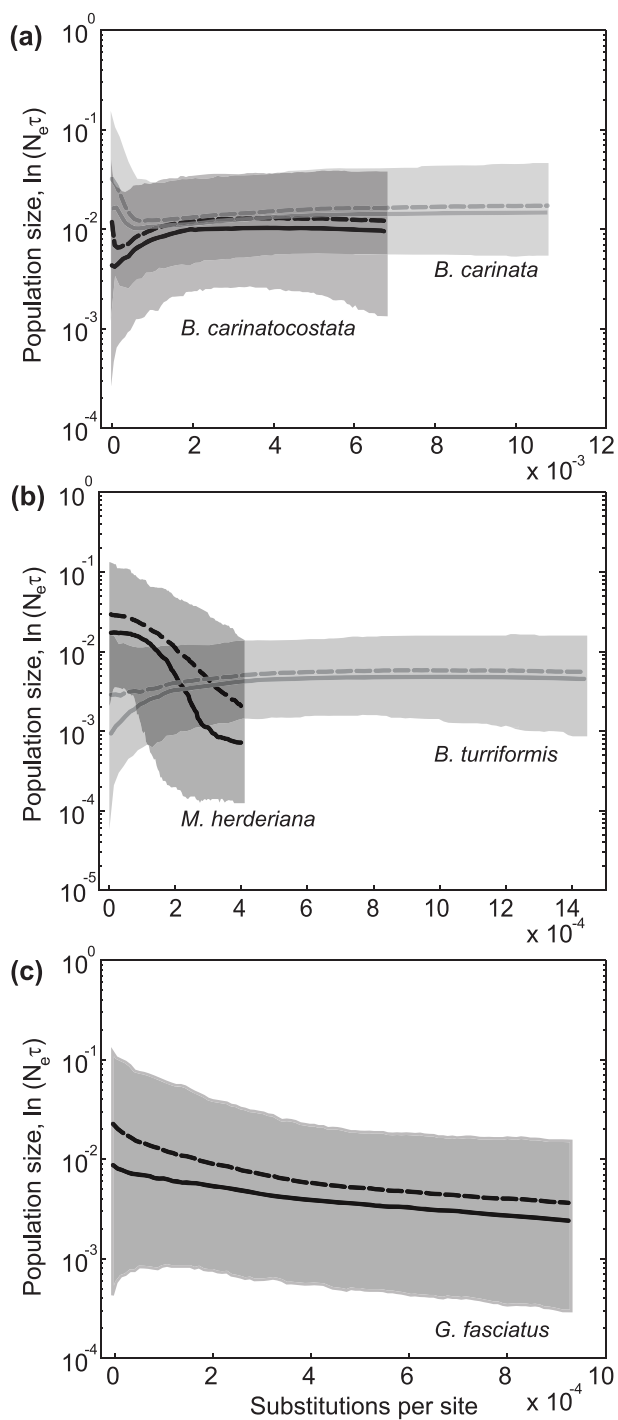

(d)

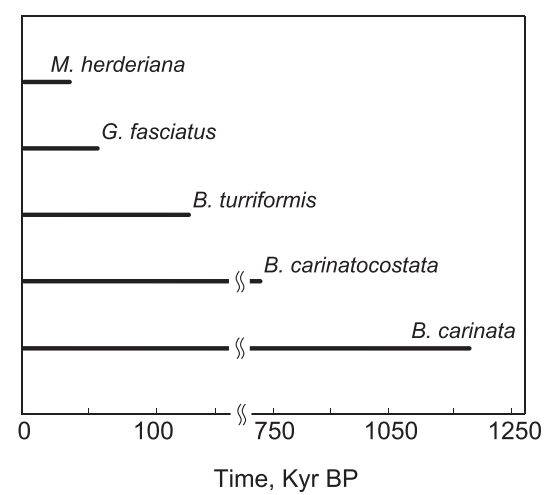

Figure 3 Inferred demographic histories for sand dwellers $B$. carinata and B. carinatocostata (a), for rock dwellers $M$. herderiana and $B$. turriformis (b) and for ecologically plastic $G$. fasciatus (c). Thick solid lines are median estimates, and the thick dashed lines are mean estimates. Grey shades show 95\% highest posterior density limits. Duration of demographic histories for the five species is compared in bottom panel (d).
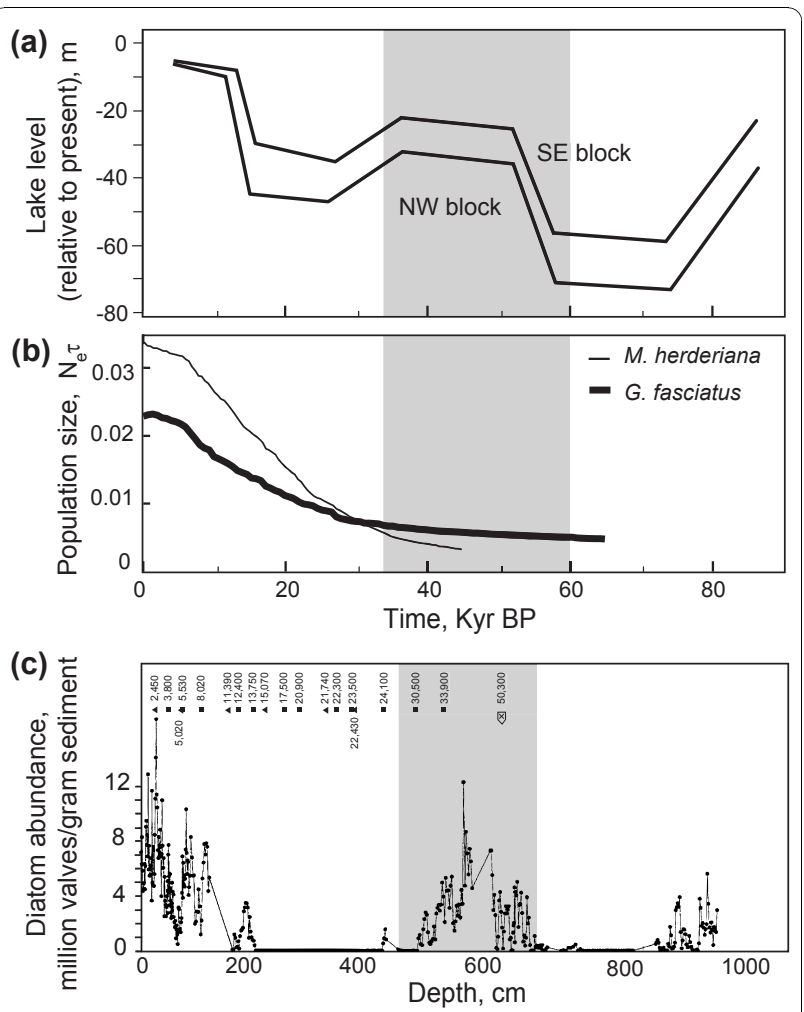

Figure 4 Calibrated demographic histories of $G$. fasciatus and $M$. herderiana and reconstructed paleoclimatic history. (a) Inferred lake water level (relative to present) based on seismic survey of the delta of the Selenga River. The two lines (NW and SE) represent results obtained using the northwestern and southeastern (respectively) blocks of the delta (see reference [32] for details); adapted from reference [32], (b) changes in population size in G. fasciatus and $M$. herderiana (mean estimates; obtained in this study) and (c) diatom abundance inferred from sedimentary drill core BDP93-2 (redrawn from [21]). In (c), solid triangles are the radiocarbon dates for the core BDP-93-1 [82,83] and squares are for core BDP93-2; the arrow indicates the $50.3 \mathrm{Kyr}$ BP correlation tie point for BDP-93 record [29]. The shaded areas correspond to Marine Isotope Stage 3.

rather different phylogeographic patterns. It was reported that $B$. carinata increases its dispersal by laying eggs on the shells of its conspecifics [40,41], and this could explain the difference between phylogeographic structures. Similarly, the rock-dweller B. turriformis displays high degree of geographical substructuring, even though significant geographical barriers between rocky habitats in the sampled shore seem absent. This more sedentary species mostly inhabits the surface of steep rocks and cliffs with individuals hanging on each other $[41,44]$ and is known as a strict specialist in regard to its feeding behaviour and overhanging slopes [44]. This high degree of specialization might reduce the dispersal ability of B. turriformis due to the lack of suitable habitats available. 
For the reconstruction of the demographic history of populations it is important to identify if a sampling set represents a single population. For $M$. herderiana we sampled most of the range of the shore where this species occurs [52] and found very little genetic differentiation. Likewise, for this species most $\mathrm{F}_{\mathrm{ST}}$ values between localities were non-significant. Baicalia carinata and G. fasciatus occur along whole shoreline of the lake and previous studies [53,54] involving samples from outside the area of the current study showed that individuals of each of the species form single populations along the southwestern shore. In our analysis, not a single pairwise comparison between localities where G. fasciatus was found exhibited significant $\mathrm{F}_{\mathrm{ST}}$ values. For $B$. carinata, significant $\mathrm{F}_{\mathrm{ST}}$ values were found between some localities (notably, between comparison involving localities 11 and 12). Similarly, $\mathrm{F}_{\mathrm{ST}}$ values estimated between localities of B. carinatocostata exhibited only few significant results. Conversely, genetic differentiation was higher in $B$. turriformis, despite the smaller sample sizes used in this study, and $\mathrm{F}_{\mathrm{ST}}$ analysis revealed significant genetic differentiation between most localities. These results confirm that samples of $M$. herderiana, B. carinata, B. carinatocostata and G. fasciatus represent populations without strong geographical substructuring, and thus are appropriate for reconstruction of demographic histories. Given the higher genetic differentiation in B. turriformis, the reconstruction of demographic histories for this species should be interpreted with caution. Recent results (Peretolchina et al. in preparation) suggest that the co-occurring populations of $B$. carinata, B. turriformis and B. carinatocostata were not influenced by interspecific geneflow during the time period covered by the current study.

Classic neutrality tests did not detect significant departures from neutrality for any of the datasets. However, the most powerful Ramos-Onsins R2 test [55] detected population growth of $M$. herderiana. For $G$. fasciatus, results of neutrality tests were not significant, but had small $\mathrm{p}$-values $(\mathrm{p}=0.08$ for $\mathrm{R} 2$ and $\mathrm{p}=0.09$ for Tajima's D test). The structure of the haplotype networks of M. herderiana and G. fasciatus, with a central abundant haplotype and a number of singleton haplotypes, also suggests population growth for these species.

Our demographic reconstructions suggest that population sizes in B. turriformis, B. carinata and B. carinatocostata were rather stable during their evolutionary histories. There are slight trends towards a decline for $B$. turriformis and $B$. carinatocostata as well as slight trend towards population growth for $B$. carinata. However, these slight trends cannot not be taken as evidence for changes in population size because as they appear, the posterior distributions widen. Conversely, BSPs suggest moderate growth for G. fasciatus, and dramatic expansion for M. herderiana. Figure 3 (d) allows to compare the duration of demographic histories for all species, and one could see that demographic histories of $M$. herderiana and G. fasciatus are short, contrary to demographic histories of $B$. turriformis, B. carinata and B. carinatocostata. Long demographic histories of $B$. carinata, B. turriformis and $B$. carinatocostata do not show response to the climatic fluctuations that are known from the paleo-record of the lake, while shorter demographic histories of $M$. herderiana and G. fasciatus exhibit strong to moderate growth. It is thus plausible that $M$. herderiana and G. fasciatus are relatively recent colonizers of the southwestern shore of Lake Baikal, while the remaining species analysed represent more ancient inhabitants of this area. Alternatively, G. fasciatus and M. herderiana populations may have recently undergone strong bottlenecks, with the growth detected reflecting the recent recovery from such bottlenecks, while the remaining species could have maintained relatively constant population sizes throughout their histories. To elucidate this, future work could focus on the analysis of nuclear gene diversity, as autosomal and mitochondrial DNA diversity are expected to show different rates of recovery from bottlenecks [56].

Calibration of demographic histories based on molecular sequences is notoriously difficult, particularly when specific rates of molecular evolution are unavailable $[57,58]$. Nevertheless, such dating can often provide rough time estimates for important events of a species' evolutionary history. After we calibrated demographic histories for populations of $M$. herderiana and G. fasciatus by applying available rates of molecular evolution, we found that the start of expansion of populations of these species coincide, and could be estimated to 25-50 Kyr BP (Figure 4). Urabe et al. [32] inferred lake-level variations from seismic surveying and core sampling of the floor of the lake, which appeared to be correlated to changes of the global climate represented by MIS. However, there is no evidence that the drop of the water level due to climate cooling could separate basins of the lake or result in any kind of geographical separation of the fauna inhabiting the southwestern shore. Diatom abundance, that could directly indicate amount of food items available for both species, is shown in Figure 4 (c). The sedimentary core BDP-93-2 from Buguldeika Saddle $[21,23]$ in concordance with cores st2 and st2-PC-2001 from Akademichesky Ridge [59] demonstrate a strongly pronounced interstadial peak at the time c. 25-60 Kyr BP. This suggests that populations of $M$. herderiana and G. fasciatus in the southwestern shore of Lake Baikal started expanding during a warm period of relatively high water level, and when the amount of food available was also rather high. While this would indicate that food availability played an important role in the population growth of these species, it should be mentioned that 
from c. 24 to c. 14 Kyr BP the amount of diatoms in the lake was very much reduced, however the populations of $M$. herderiana and G. fasciatus do not appear to have stopped expanding. Data on sedimentary photosynthetic pigments suggests that, despite the reduced bioproductivity of the lake, green algae, diatoms and dinoflagellates were still present in the lake between 16 and $27 \mathrm{Kyr}$ BP [25]. Therefore, it is possible that during this period the abovementioned species relied on other food items. At any rate, the simultaneous growth detected in M. herderiana and G. fasciatus suggests that environmental factors promoted the population growth of these species in the southwestern shore of Lake Baikal. High resemblance of demographic histories of M. herderiana and G. fasciatus, a species known to be of high invasive capability, highlights the strong dispersal potential of $M$. herderiana and its ability to expand its population size when environmental conditions are favorable.

\section{Conclusions}

Demographic histories of populations reflect complex interplay between past environmental changes and ecological properties of species. We investigated how five invertebrate species from the same geographical area and with similar food preferences reacted to the environmental changes known to have happened in the lake. We show that intrinsic ecological specialization plays an important role in the demographic response of the species. In particular, high dispersal abilities and lack of strong habitat preference allowed species to find appropriate habitats and expand their populations in response to favourable environmental conditions.

\section{Methods}

Sampling, DNA extraction, amplification and sequencing

Gastropods were collected by dredge or dives along southwestern littoral of the lake at depths of 5 to 40 meters. After preliminary sorting of benthic samples, gastropods were fixed in $80 \%$ ethanol for 24 hours with subsequent ethanol change to $70 \%$ solution and kept until DNA extraction. G. fasciatus specimens were collected from the shore, using handle-nets, from the depth of 0 to $1.0 \mathrm{~m}$. Specimens were fixed in $96 \%$ ethanol. After incubation at $4^{\circ} \mathrm{C}$ for two to three days, $96 \%$ ethanol was discharged, and the samples were kept at $4^{\circ} \mathrm{C}$ in $70 \%$ ethanol. The list of sampling localities is shown in Table 1 (for details see Additional file 1). Relatively few individuals of $B$. turriformis and $B$. carinatocosta are used in this study due to a scarce number of samples collected, which is reflective of the rarity of these species [60].

DNA extraction and PCR amplification were performed according to protocols described in Peretolchina et al. [54] for the gastropods and in Gomanenko et al.
[53] for G. fasciatus. The CO1 fragment of mitochondrial DNA was amplified using the universal DNA primers of Folmer et al. [61]. Sequencing reactions were performed in the forward direction using the Quick Start Kit (Beckman Coulter Inc.). Sequencing was then carried on in either a 373A DNA Sequencer (Applied Biosystems) or a CEQ 8800 DNA sequencer (Beckman Coulter Inc).

\section{Phylogeography and reconstruction of demographic histories}

The DNA sequences were aligned using ClustalW v. 1.4 [62], and resulting alignment was translated to check for the presence of stop codons.

Haplotype networks were constructed using the program TCS v. 1.2.1 [63]. The threshold value of the statistical parsimony algorithm, defining the maximal number of mutational connections between pairs of haplotypes within the same network, was set to 0.95 [64].

For each species, we estimated $\mathrm{F}_{\mathrm{ST}}$ values between pairs of localities in Arlequin v. 3.5 [65]. We estimated $F_{\mathrm{ST}}$ values using haplotype frequencies, using a distance matrix between haplotypes based on the Kimura's two-parameter model [66] and using a distance matrix between haplotypes based on Tamura-Nei distance [67]. Significance of $\mathrm{F}_{\mathrm{ST}}$ values was estimated using 10000 permutations, and resulting p-values corrected for multiple testing using the False Discovery Rate procedure of [68].

We used DNA SP v. 5.10.00 [69] to produce mismatch distributions for each species as well as to perform the following tests of neutrality: Tajima's D test [70], Fu's Fs statistics [71] and $R 2$ test [55]. In order to distinguish between population growth and selection, we used $\mathrm{H}$ statistics [72].

Bayesian skyline plots were constructed using BEAST v. 1.5.1 [73,74]. Substitution model for each dataset was chosen using jModeltest v. $0.1[75,76]$ based on the Akaike information criterion [77]. For B. carinata and B. carinatocostata jModeltest selected the HasegawaKishino-Yano (HKY) model [78] with a proportion of invariable sites $(+\mathrm{I})$ and a gamma distributed rate heterogeneity among the remaining sites $(+G)$. For the remaining three species the best fitting model was HKY. For G. fasciatus, we could not obtain values of ESS (Effective Sample Size) exceeding the recommended value of 200 using HKY model proposed by jModeltest, so we applied the GTR substitution model [79]. In order to check if this change of substitution model for G. fasciatus affects the recovered demographic history we compared BSPs for both substitution models. BEAST analysis was performed assuming selected substitution models but parameters were estimated from data. We ran chains of 150 million steps for $M$. herderiana, 20 million steps for $B$. carinata and G. fasciatus, and 10 million steps for $B$. 
carinatocostata and B. turriformis to obtain in each run ESS values $>200$. For each species we performed at least 2 individual runs and compared the results to check for convergence. Data from two independent runs for each species was combined using Log Combiner v1.5.1 [73,74] in order to observe resulting BSPs.

To convert the time scale of demographic histories from substitutions per site into years, we used earlier suggested divergence rate of $1.83 \% / \mathrm{Myr}$ (million years) for gastropods [80]. Since there is no calibration of molecular clock available for amphipods, for G. fasciatus we used average from the reported rates (1.3-1.9\%/Myr) of arthropods [81]. Once absolute time scales were obtained for the species' demographic histories, we matched these histories to paleoclimatic events estimated through radiocarbon calibrations of sedimentary cores [21,32].

\section{Additional material}

Additional file 1: Detailed description of each individual used in the study. Description includes isolate identification, taxonomic status, locality and year of capture, collectors and accession numbers.

Additional file 2: Tables of pairwise $F_{S T}$ values between localities for each studied species, with the $p$-values given in parentheses. Significant values before correction for multiple testing are marked with asterisk. Significant values after correction for multiple testing are shown in bold. Loc is locality number (see Figure 1), $N$ is number of samples.

Additional file 3: BSP reconstructions for G. fasciatus using different substitution models. Comparison of demographic reconstructions using GTR and HKY substitution models. Thick solid lines are median estimates, and thick dashed lines are mean estimates, shades show 95\% highest posterior density limits.

Additional file 4: Maps of underwater landscapes of the study area. Types of bottom substrates at different depths of the lake. The maps were redrawn from Karabanov EB, Sideleva VG, Izhboldina LA, Mel'nik NG, Zubin AA, Zubina LV, Smirnov NV, Parfenova W, Fedorova LA, Gorbunova LA, Kulishenko YuL. (1990) Underwater Landscapes of Baikal. Novosibirsk: Nauka Publ.,184 pp. (In Russian).

\section{Acknowledgements}

We would like to thank Dr. L. Kravtsova, Dr. E. Likhoshway, Prof. Dr. C. Sturmbauer and two anonymous reviewers for useful comments on earlier versions of this manuscript. Dr. R. Kamaltynov and Dr. T. Sitnikova are acknowledged for their help with identification of the samples and discussion on ecological properties of the species studied. Z. Grigoreva and A. Novikov are acknowledged for assistance with the laboratory work. This study was supported by RFBR grant 09-04-00972-a to D. Sherbakov. Part of the samples used in this study was collected during an expedition financed by ESF Project MOLARCH. B. Nevado was supported by PhD grant SFRH/BD/ 17704/2004 from the Fundação para a Ciência e Tecnologia. J. Petunina was supported by Marie Curie Fellowship during her four month stay in the University of Leeds.

\section{Author details}

'Laboratory of Molecular Systematics, Limnological Institute of the Siberian Branch of the Russian Academy of Sciences, Ulan-Batorskaya 3, 664033 Irkutsk, Russia. ${ }^{2}$ Evolution and Ecology Program, International Institute for Applied Systems Analysis, Schlossplatz 1, A-2361 Laxenburg, Austria. ${ }^{3}$ Vertebrate Department, Royal Belgian Institute of Natural Sciences, Vautierstraat 29, 1000 Brussels, Belgium. ${ }^{4}$ Evolutionary Ecology Group, University of Antwerp, Groenenborgerlaan 171, B-2020 Antwerp, Belgium. ${ }^{5}$ Faculty of Biology and Soil Science, Irkutsk State University, Sukhe-Batora 5 664003 Irkutsk, Russia.

\section{Authors' contributions}

VF carried out molecular genetic studies on $M$. herderiana, performed the analysis and drafted the manuscript. BN participated in the analysis and helped to draft the manuscript. TP and JP carried out molecular genetic studies on Baicalia spp. and G. fasciatus. DS coordinated the design of the study and has been involved in drafting of the manuscript. All authors read and approved the manuscript.

Received: 18 April 2010 Accepted: 23 October 2010 Published: 23 October 2010

\section{References}

1. Hewitt G: The genetic legacy of the Quaternary ice ages. Nature 2000, 405:907-913

2. Hewitt GM: Genetic consequences of climatic oscillations in the Quaternary. Phil. Trans. R. Soc.B 2004, 359:183-195.

3. Lessa EP, Cook JA, Patton JL: Genetic footprints of demographic expansion in North America, but not Amazonia, during the Late Quaternary. Proc Nat Acad Sc 2003, 100:10331-10334.

4. Márquez A, Maldonado J, González S, Beccaceci M, Garcia J, Duarte J: Phylogeography and Pleistocene demographic history of the endangered marsh deer (Blastocerus dichotomus) from the Río de la Plata Basin. Conserv Genetics 2006, 7:563-575.

5. Shepard DB, Burbrink FT: Lineage diversification and historical demography of a sky island salamander, Plethodon ouachitae, from the Interior Highlands. Mol Ecol 2008, 17:5315-5335.

6. Shennan I: Sea level studies. In Encyclopedia of Quaternary Science. Edited by: Elias SA. Oxford: Elsevier; 2007:2967-2974.

7. Wares JP: Community genetics in the Northwestern Atlantic intertidal. Mol Ecol 2002, 11:1131-1144.

8. Crandall ED, Frey MA, Grosberg RK, Barber PH: Contrasting demographic history and phylogeographical patterns in two Indo-Pacific gastropods. Mol Ecol 2008, 17:611-626.

9. Davison A, Chiba S: Contrasting response to Pleistocene climate change by ground-living and arboreal Mandarina snails from the oceanic Hahajima archipelago. Phil Trans R Soc B 2008, 363:3391-3400.

10. Marko PB, Hoffman JM, Emme SA, Mcgovern TM, Keever CC, Cox LN: The 'Expansion-Contraction' model of Pleistocene biogeography: rocky shores suffer a sea change? Mol Ecol 2010, 19:146-169.

11. Hoelzel AR, Natoli A, Dahlheim ME, Olavarria C, Baird RW, Black NA: Low worldwide genetic diversity in the killer whale (Orcinus orca): implications for demographic history. Proc Royal Soc B 2002, 269:1467-1473

12. Genner MJ, Knight ME, Haesler MP, Turner GF: Establishment and expansion of Lake Malawi rock fish populations after a dramatic Late Pleistocene lake level rise. Mol Ecol 2010, 19:170-182.

13. Kozhov M: In Lake Baikal and Its Life. Edited by: Junk W. The Hague, Netherlands; 1963.

14. Short DA, Mengel JG, Crowley TJ, Hyde WT, North GR: Filtering of Milankovitch cycles by earth's geography. Quat Res 1991, 35:157-173.

15. Williams DF, Kuzmin Ml, Prokopenko AA, Karabanov EB, Khursevich GK, Bezrukova EV: The Lake Baikal drilling project in the context of a global lake drilling initiative. Quat Int 2001, 80-81:3-18.

16. Kashiwaya K: Long Continental Records from Lake Baikal Tokyo: Springer; 2003.

17. Grachev MA, Vorobyova SS, Likhoshway YV, Goldberg EL, Ziborova GA, Levina OV, Khlystov OM: A high-resolution diatom record of the palaeoclimates of East Siberia for the last 2.5 My from Lake Baikal. Quat Sci Rev 1998, 17:1101-1106.

18. Bradbury JP, Bezrukova YV, Chernyaeva GP, Colman SM, Khursevich G, King JW, Likhoshway YV: A synthesis of post-glacial diatom records from Lake Baikal. J Paleolimnol 1994, 10:213-252.

19. Colman SM, Peck JA, Karabanov EB, Carter SJ, Bradbury JP, King JW, Williams DF: Continental climate response to orbital forcing from biogenic silica records in Lake Baikal. Nature 1995, 378:769-771.

20. Williams DF: Lake Baikal Record of Continental Climate Response to Orbital Insolation During the Past 5 Million Years. Science 1997, 278:1114-1117.

21. Prokopenko AA, Karabanov EB, Williams DF, Kuzmin MI, Khursevich GK, Gvozdkov AA: The detailed record of climatic events during the past 
75,000 yrs BP from the Lake Baikal drill core BDP-93-2. Quat Int 2001, 8081:59-68.

22. Prokopenko AA, Williams DF, Kuzmin MI, Karabanov EB, Khursevich GK Peck JA: Muted climate variations in continental Siberia during the midPleistocene epoch. Nature 2002, 418:65-68.

23. Edlund MB, Stoermer EF: A 200,000-year, high-resolution record of diatom productivity and community makeup from Lake Baikal shows high correspondence to the marine oxygen-isotope record of climate change. Limnol Oceanogr 2000, 45:948-962.

24. Fietz S, Nicklisch A, Oberhänsli H: Phytoplankton response to climate changes in Lake Baikal during the Holocene and Kazantsevo Interglacials assessed from sedimentary pigments. J Paleolimnol 2007, 37:177-203.

25. Soma $Y$, Tani $Y$, Soma M, Mitake $H$, Kurihara $R$, Hashomoto $S$, Watanabe $T$, Nakamura T: Sedimentary Steryl Chlorin Esters (SCEs) and Other Photosynthetic Pigments as Indicators of Paleolimnological Change Over the Last 28,000 Years from the Buguldeika Saddle of Lake Baikal. J Paleolimnol 2007, 37:163-175.

26. Goldberg E, Phedorin M, Chebykin E, Zolotarev K, Zhuchenko N: Decadecentenary resolution records of climate changes in East Siberia from elements in the bottom sediments of lake Baikal for the last $150 \mathrm{kyr}$. Nucl Instrum Methods Phys Res A 2007, 575:193-195.

27. Prokopenko AA, Williams DF, Karabanov EB, Khursevich GK: Continental response to Heinrich events and Bond cycles in sedimentary record of Lake Baikal, Siberia. Glob Planet Change 2001, 28:217-226.

28. Swann G, Mackay A, Leng M, Demory F: Climatic change in Central Asia during MIS 3/2: a case study using biological responses from Lake Baikal. Glob Planet Change 2005, 46:235-253.

29. Colman SM, Peck JA, Hatton J, Karabanov EB, King JW: Biogenic silica from the BDP93 drill site and adjacent areas of the Selenga Delta, Lake Baikal, Siberia. J Paleolimnol 1999, 21:9-17.

30. Bezrukova EV, Bogdanov YA, Williams DF, Granina L, Grachev MA Ignatova N, Karabanov EB, Kuptsov VM, Kurylev A, Letunova PP, Likhoshway WV, Chernyaeva GP, Shimaraeva MK, Yakujshin AO: A dramatic change of the ecological system of Lake Baikal in the Holocene. Doklady AN SSSR 1991, 321:1032-1037, (In Russian).

31. Chebykin EP, Edgington DN, Grachev MA, Zheleznyakova TO, Vorobyova SS, Kulikova NS, Azarova IN, Khlystov OM, Goldberg EL: Abrupt increase in precipitation and weathering of soils in East Siberia coincident with the end of the last glaciation (15 cal kyr BP). Earth Planet Sci Let 2002, 200:167-175.

32. Urabe A, Tateishi M, Inouchi $Y$, Matsuoka $H$, Inoue T, Dmytriev $A$, Khlystov OM: Lake-level changes during the past 100,000 years at Lake Baikal, southern Siberia. Quat Res 2004, 62:214-222.

33. Khlystov O, Khanaev I, Grachev M: Evidence of lowstand of Lake Baikal during the Last Glaciation. Doklady Earth Sciences 2008, 422:1133-1136, (In Russian).

34. Sherbakov D: Molecular phylogenetic studies on the origin of biodiversity in Lake Baikal. Trends Ecol Evol 1999, 14:92-95.

35. Galarza JA, Carreras-Carbonell J, Macpherson E, Pascual M, Roques S, Turner GF, Rico C: The influence of oceanographic fronts and early-lifehistory traits on connectivity among littoral fish species. Proc Nat Acad SC 2009, 106:1473-1478

36. Kelly RP, Palumbi SR: Genetic Structure Among 50 Species of the Northeastern Pacific Rocky Intertidal Community. PLOS ONE 2010, 5:e8594.

37. Fauvelot $C$, Bernardi $G$, Planes S: Reductions in the mitochondrial DNA diversity of coral reef fish provide evidence of population bottlenecks resulting from Holocene sea-level change. Evolution 2003, 57:1571-1583.

38. Janko K, Lecointre G, DeVries A, Couloux A, Cruaud C, Marshall C: Did glacial advances during the Pleistocene influence differently the demographic histories of benthic and pelagic Antarctic shelf fishes? Inferences from intraspecific mitochondrial and nuclear DNA sequence diversity. BMC Evol Biol 2007, 7:220

39. Jadin VI: Fresh-water mollusks of the USSR Moscow: USSR Academy of Sciences; 1952.

40. Sitnikova $T$, Roepstorf $P$, Riedel F: Reproduction, duration of embryogenesis, egg capsules and protoconchs of gastropods of the family Baicaliidae (Caenogastropoda) endemic to Lake Baikal. Malacologia 2001, 43:59-85
41. Korobkova N, Sitnikova T, Roepstorf P: Intraspecific variation of the Baikalian endemic gastropod Baicalia carinata (W. Dybowski, 1875) (Caenogastropoda, Baicaliidae). Hydrobiologia 2006, 568:161-166.

42. Panov VE: Establishment of the Baikalian endemic amphipod Gmelinoides fasciatus Stebb. in Lake Ladoga. Hydrobiologia 1996, 322:187-192.

43. Berezina N, Zhakova L, Zaporozhets N, Panov VE: Key role of the amphipod Gmelinoides fasciatus in reed beds of Lake Ladoga. Bor Env Res 2009, 14:404-414

44. Roepstorf P, Sitnikova TY, Timoshkin O, Pomazkina G: Observations on stomach contents, food uptake and feeding strategies of endemic baikalian gastropods. In Berliner Palaobiologische Abhandlungen. Volume 4. Berlin; 2002:157-181.

45. Slatkin M, Hudson RR: Pairwise Comparisons of Mitochondrial DNA Sequences in Stable and Exponentially Growing Populations. Genetics 1991, 129:555-562.

46. Rogers $\mathrm{A}$, Harpending $\mathrm{H}$ : Population growth makes waves in the distribution of pairwise genetic differences. Mol Biol Evol 1992, 9:552-569.

47. Felsenstein J: Accuracy of Coalescent Likelihood Estimates: Do We Need More Sites, More Sequences, or More Loci? Mol Biol Evol 2006, 23:691-700.

48. Koblmüller S, Sefc KM, Duftner N, Warum M, Sturmbauer C: Genetic population structure as indirect measure of dispersal ability in a Lake Tanganyika cichlid. Genetica 2007, 130:121-131.

49. Bazikalova AY: In The amphipods of Lake Baikal. Proceedings of the Baikal Limnological Station. Volume 11. Moscow-Leningrad: AN SSSR; 1945, (In Russian)

50. Kamaltynov RM: Amphipoda (Gammaroidea). In Annotated List of Fauna of Lake Baikal and Its Drainage Area. Volume 1. Edited by: Timoshkin OA. Novosibirsk: Nauka; 2001:572-832.

51. Berezina N: Interspecific interactions of amphipods Gammarus lacustris and Gmelinoides fasciatus. Russian J Ecology 2009, 40:81-85.

52. Maximova N: Biology and distibution of Baicalian gastropod Maackia (Eubaicalia) Herderiana (Lindholm, 1909) (Gastropoda: Caenogastropoda: Baicaliidae). PhD thesis, Irkutsk 2007, (In Russian).

53. Gomanenko G, Kamaltynov R, Kuzmenkova Z, Berenos K, Sherbakov D: Population Structure of the Baikalian Amphipod Gmelinoides fasciatus (Stebbing). Russian J Genetics 2005, 41:907-912.

54. Peretolchina T, Bukin Y, Sitnikova T, Sherbakov D: Genetic differentiation of the endemic Baikalian mollusk Baicalia carinata (Mollusca: Caenogastropoda). Russian J Genetics 2007, 43:1400-1407.

55. Ramos-Onsins SE, Rozas J: Statistical Properties of New Neutrality Tests Against Population Growth. Mol Biol Evol 2002, 19:2092-2100.

56. Pool JE, Nielsen R: Population size changes reshape genomic patterns of diversity. Evolution 2007, 61:3001-3006.

57. Arbogast BS, Edwards SV, Wakeley J, Beerli P, Slowinski JB: Estimating Divergence Times from Molecular Data on Phylogenetic and Population Genetic Timescales. Ann Rev Ecol Syst 2002, 33:707-740.

58. Pulquério MJ, Nichols RA: Dates from the molecular clock: how wrong can we be? Trends Ecol Evol 2007, 22:180-184.

59. Goldberg E, Chebykin E, Zhuchenko N, Vorobyeva S, Stepanova O, Khlystov O, Ivanov E, Weinberg E, Gvozdkov A: Uranium isotopes as proxies of the environmental history of the Lake Baikal watershed (East Siberia) during the past 150 ka. Palaeogeo Palaeoclimat Palaeoecol 2010, 294:16-29

60. Kozhov M: In Molluscs of Lake Baikal. Systematics, distribution, ecology, some data on the genesis and history. Proceedings of the Baikal Limnological Station. Volume 8. Moscow-Leningrad: AN SSSR; 1936, (In Russian).

61. Folmer O, Black M, Hoeh W, Lutz R, Vrijenhoek R: DNA primers for amplification of mitochondrial cytochrome $c$ oxidase subunit I from diverse metazoan invertebrates. Mol Marine Biol Biotechnol 1994, 3:294-299

62. Thompson JD, Higgins DG, Gibson TJ: CLUSTAL W: improving the sensitivity of progressive multiple sequence alignment through sequence weighting, position-specific gap penalties and weight matrix choice. Nucl Acids Res 1994, 22:4673-4680.

63. Clement M, Posada D, Crandall KA: TCS: a computer program to estimate gene genealogies. Mol Ecol 2000, 9:1657-1659.

64. Templeton AR, Crandall KA, Sing CF: A Cladistic Analysis of Phenotypic Associations With Haplotypes Inferred From Restriction Endonuclease Mapping and DNA Sequence Data. III. Cladogram Estimation. Genetics 1992, 132:619-633. 
65. Excoffier L, Laval G, Schneider S: Arlequin (version 3.0): An integrated software package for population genetics data analysis. Evol Bioinform Online 2005, 1:47-50

66. Kimura M: A simple method for estimating evolutionary rates of base substitutions through comparative studies of nucleotide sequences. Mol Evol 1980, 16:111-120.

67. Tamura K, Nei M: Estimation of the number of nucleotide substitutions in the control region of mitochondrial DNA in humans and chimpanzees. Mol Biol Evol 1993, 10:512-526.

68. Benjamini Y, Hochberg Y: Controlling the False Discovery Rate: A Practical and Powerful Approach to Multiple Testing. J R Stat Soc B 1995, 57:289-300.

69. Librado P, Rozas J: DnaSP v5: a software for comprehensive analysis of DNA polymorphism data. Bioinformatics 2009, 25:1451-1452.

70. Tajima F: Statistical Method for Testing the Neutral Mutation Hypothesis by DNA Polymorphism. Genetics 1989, 123:585-595.

71. Fu YX: Statistical tests of neutrality of mutations against population growth, hitchhiking and background selection. Genetics 1997 147:915-925.

72. Fay JC, Wu C: Hitchhiking Under Positive Darwinian Selection. Genetics 2000, 155:1405-1413.

73. Drummond AJ, Rambaut A, Shapiro B, Pybus OG: Bayesian Coalescent Inference of Past Population Dynamics from Molecular Sequences. Mol Biol Evol 2005, 22:1185-1192.

74. Drummond A, Rambaut A: BEAST: Bayesian evolutionary analysis by sampling trees. BMC Evol Biol 2007, 7:214

75. Posada D: jModelTest: Phylogenetic Model Averaging. Mol Biol Evol 2008, 25:1253-1256.

76. Guindon S, Gascuel O: A Simple, Fast, and Accurate Algorithm to Estimate Large Phylogenies by Maximum Likelihood. Syst Biol 2003, 52:696-704.

77. Akaike H: A New Look at the Statistical Model Identification. IEEE Trans Autom Control 1974, 19:723-730.

78. Hasegawa M, Kishino $H$, Yano T: Dating of the human-ape splitting by a molecular clock of mitochondrial DNA. Mol Evol 1985, 22:160-174.

79. Tavaré S: Some Probabilistic and Statistical Problems in the Analysis of DNA Sequences. In American Mathematical Society: Lectures on Mathematics in the Life Sciences. Volume 17. Amer Mathematical Society; 1986:86-57.

80. Wilke T: Salenthydrobia gen. nov. (Rissooidea: Hydrobiidae): a potential relict of the Messinian salinity crisis. Zool J Linn Soc 2003, 137:319-336.

81. Quek S, Davies SJ, Itino T, Pierce NE: Codiversification in an ant-plant mutualism: stem texture and the evolution of host use in Crematogaster (Formicidae: Myrmicinae) inhabitants of Macaranga (Euphorbiaceae). Evolution 2004, 58:554-570.

82. BDP-Members: Results of the first drilled borehole at Lake Baikal near the Buguldeika Isthmus. Russian J Geology and Geophysics 1995, 36:3-32.

83. Colman SM, Jones GA, Rubin M, King JW, Peck JA, Orem WH: AMS radiocarbon analyses from Lake Baikal, Siberia: Challanges of dating sediments from a large, oligotrophic lake. Quat Sci Rev 1996, 15:669-684.

doi:10.1186/1471-2148-10-320

Cite this article as: Fazalova et al:: When environmental changes do not cause geographic separation of fauna: differential responses of Baikalian invertebrates. BMC Evolutionary Biology 2010 10:320.

\section{Submit your next manuscript to BioMed Central and take full advantage of:}

- Convenient online submission

- Thorough peer review

- No space constraints or color figure charges

- Immediate publication on acceptance

- Inclusion in PubMed, CAS, Scopus and Google Scholar

- Research which is freely available for redistribution

Submit your manuscript at www.biomedcentral.com/submit
C) Biomed Central 